University of Louisville

ThinkIR: The University of Louisville's Institutional Repository

Faculty Scholarship

Spring 2013

\title{
No One Who Reads the History of Hayti Can Doubt the Capacity of Colored Men: Racial Formation and Atlantic Rehabilitation in New York City's Early Black Press, 1827-1841
}

Charlton W. Yingling

University of Louisville, charlton.yingling@louisville.edu

Follow this and additional works at: https://ir.library.louisville.edu/faculty

Part of the African American Studies Commons, American Studies Commons, History Commons, and the Publishing Commons

Original Publication Information

Yingling, Charlton W. "No One Who Reads the History of Hayti Can Doubt the Capacity of Colored Men: Racial Formation and Atlantic Rehabilitation in New York City's Early Black Press, 1827-1841." 2013. Early American Studies: An Interdisciplinary Journal 11(2): 314-348.

doi:10.1353/eam.2013.0014.

ThinkIR Citation

Yingling, Charlton W., "No One Who Reads the History of Hayti Can Doubt the Capacity of Colored Men: Racial Formation and Atlantic Rehabilitation in New York City's Early Black Press, 1827-1841" (2013). Faculty Scholarship. 443.

https://ir.library.louisville.edu/faculty/443

This Article is brought to you for free and open access by ThinkIR: The University of Louisville's Institutional Repository. It has been accepted for inclusion in Faculty Scholarship by an authorized administrator of ThinkIR: The University of Louisville's Institutional Repository. For more information, please contact thinkir@louisville.edu. 


\title{
No One Who Reads the History of Hayti Can Doubt the Capacity of Colored Men
}

Racial Formation and Atlantic Rehabilitation in New York City’s Early Black Press, 1827-1841

\author{
CHARLTON W. YINGLING \\ University of South Carolina
}

\begin{abstract}
From 1827 to 1841 the black newspapers Freedom's Journal and the Colored American of New York City were venues for one of the first significant racial projects in the United States. To counter aspersions against their race, the editors of these publications renegotiated their community's identity within the matrix of the Black Atlantic away from waning discourses of a collective African past. First, Freedom's Journal used the Haitian Revolution to exemplify resistance, abolitionism, and autonomy. The Colored American later projected the Republic of Haiti as a model of governance, prosperity, and refinement to serve this community's own evolving ambitions of citizenship, inclusion, and rights.
\end{abstract}

On March 15, 1838, the Colored American, which operated in New York City as one of the first black newspapers in the United States, pronounced, "No one who reads, with an unprejudiced mind, the history of Hayti . . . can doubt the capacity of colored men, nor the propriety of removing all their disabilities." 1 This pronouncement was prefatory to a series of letters written by an unnamed slaveholding planter from the U.S. South during his one-month stay in Haiti. The Colored American showed that, despite the slaveholder's likely racial, class, and economic proclivities, he was nonethe-

Special thanks to Matt Childs, Dave Roediger, and Michael Woods for their thoughtful comments, and thanks to Jane Landers and Dan Littlefield for their input. I am grateful for the constructive feedback from Dallett Hemphill and the anonymous reviewers.

1. "Republic of Hayti," Colored American, March 15, 1838, 2. Cheryl I. Harris, "Whiteness as Property," Harvard Law Review 106, no. 8 (June 1993): 1729-37.

Early American Studies (Spring 2013)

Copyright (C) 2013 The McNeil Center for Early American Studies. All rights reserved. 
less overwhelmed by Haitians' morality, prosperity, hospitality, health, and intellectual attainments. ${ }^{2}$ The planter said of Haiti, "The state of society here proves very clearly to me, that our main argument to excuse our persecution of color . . . if unsupported by law, soon melts, and is dissolved by our moral relations.... annul the privileges, and these governments become republican, or of equal laws. This government of Haiti approaches nearer to pure republicanism than any other, now in use or on record." ${ }^{3}$ This sweeping dictum not only questioned inherent racial difference and the precepts of racial oppression, but also laid bare its legal, structural support. As editors of the early black press used Haiti for racial rehabilitation, such laudatory articles became common.

For five decades from the start of the Haitian Revolution in 1791 to the closing of the Colored American in 1841, the Black Atlantic had varyingly negotiated Haiti's example of black talent and independence that had, to many, legitimated the efficacy of universal freedom and inalienable rights. Haiti's autonomy inspired the ambitions, informed the resistance, and instructed the bigoted adversaries of the free black community of New York City. Incidentally, the editors of the early black press came also to imbue the symbol of Haiti with selective values and evidence, initiating a dynamic reciprocation in which they often projected meaning on an imagined Haiti as much as Haitian realities influenced them in their own right. ${ }^{4}$ The editors thought the dissemination of a rehabilitated Haiti could precipitate egalitarian redemption; knowledge was power.

The Colored American was not the first black newspaper to adjoin its community's legacy and future to the model of Haiti. In March 1827 Freedom's Journal was established in New York City as the first black newspaper in the United States. ${ }^{5}$ In its introductory article it posed this question to its readers: "If ignorance, poverty and degradation have hitherto been our unhappy lot; has the Eternal decree gone forth, that our race alone, are to remain in this state?" The article refuted that prospect and explicitly cited Haiti as a beacon of hope for all blacks. ${ }^{6}$ Freedom's Journal featured numerous articles on the Haitian Revolution, which it heralded as the "revolution

2. "Letters on Haiti. Letter II," Colored American, March 22, 1838, 1.

3. "Letters on Haiti. Letter I," Colored American, March 15, 1838, 1. Harris, "Whiteness as Property," 1716-21.

4. "Republic of Hayti," Colored American, March 15, 1838, 2.

5. Frankie Hutton, The Early Black Press in America, 1827-1860 (Westport, Conn.: Greenwood Press, 1993), 4-5.

6. Samuel Cornish and John Russwurm, "To Our Patrons," Freedom's Journal, March 16, 1827, 1. 
unexampled in the history of man." The Haitian Revolution embodied hope for abolitionism at home and throughout the Atlantic, and the Republic of Haiti was a model of black citizenship and governance that came to mediate black civic ambitions in the North. Local abolition was legislatively enacted in New York in 1827, and thereafter as challenges of public and legal inclusion as citizens developed from more focused abolitionism, the uses of Haiti also evolved for the black community of New York City. ${ }^{8}$

Both newspapers were acutely aware of Haiti's symbolic and material power, which they endeavored to project to their readership through consistently positive images. These articles and editorial choices provide vital windows into the cadre of educated and politically minded free black professionals who published them. Not only did the operators of both newspapers know each other and at times collaborate, but Freedom's Journal and the Colored American shared a common founding editor in Samuel Cornish. Collectively these publications are representative samples of common sense positions and outlooks held by this activist network. The community experienced dissent, particularly on colonization, but overall it embraced the unifying meaning and force of Haiti, though uses of the revolution and republic varied. ${ }^{9}$

I argue that within this context from 1827 to 1841 the free black press of New York City undertook a racial formation project that centered the

7. "Hayti, No. III," Freedom's Journal, May 4, 1827, 2.

8. Graham Russell Hodges, Root E Branch: African Americans in New York and East Jersey, 1613-1863 (Chapel Hill: University of North Carolina Press, 1999), 227-62. David N. Gellman, Emancipating New York: The Politics of Slavery and Freedom, 1777-1827 (Baton Rouge: Louisiana State University Press, 2006), 189219.

9. Jacqueline Bacon, Freedom's Journal: The First African-American Nerwspaper (Lanham, Md.: Lexington Books, 2007), 1-5. Charles Simmons, The African American Press: With Special Reference to Four Nerwspapers, 1827-1965 (Jefferson, N.C.: McFarland, 1998), 9-10. Renate Holub, Antonio Gramsci: Beyond Marxism and Postmodernism (New York: Routledge, 1992), 51. Dean Wolfe Manders, The Hegemony of Common Sense: Wisdom and Mystification in Everyday Life (New York: Peter Lang, 2005), 18. "American Colonization," Colored American, August 11, 1838, 2. Samuel Cornish and John Russwurm, "Colonization Society," Freedom's Journal, September 14, 1827, 3. "Immediate Emancipation," Colored American, November 16, 1839, 3. "Slavery," Freedom's Journal, December 5, 1828, 2. "Intellectual Faculties of the Negro," Colored American, August 22, 1840, 1. "Toussaint L'Ouverture," Freedom's Journal, May 4, 1827, 2. Leslie M. Harris, In the Shadow of Slavery: African Americans in New York City, 1626-1863 (Chicago: University of Chicago Press, 2003), 203. 
racially redemptive power of Haiti as its incontrovertible evidence, countering hegemonic aspersions against blacks' intelligence, solvency, social responsibility, and ethics. ${ }^{10}$ It was one of the first large-scale racial projects in the United States, and was the first such effort to deliberately utilize the wide-reaching discursive power of print media. ${ }^{11}$ These journalists, operating in a port enmeshed within the Atlantic world, were uniquely placed to refract rehabilitated images of Haiti toward destabilizing racial oppression. ${ }^{12}$ They also monitored black abolitionism in France, postemancipation struggles throughout the Caribbean, and the vagaries of African colonization. ${ }^{13}$ These broader purviews of analogous groups and wider struggles positioned them as informational intermediaries within the Black Atlantic and afforded them a worldview that was subsequently consumed by their readers. Specifically using Haiti entailed a renegotiation of the editors' own identity and location within this broader matrix of the Black Atlantic. Whereas U.S. free blacks had formerly invoked the failed revolutionary promises of the

10. Michael Omi and Howard Winant, Racial Formation in the United States: From the 1960s to the 1990s (New York: Routledge, 1994). See also Circe Sturm, Blood Politics: Race, Culture, and Identity in the Cherokee Nation of Oklahoma (Berkeley: University of California Press, 2002), 20-22; Korie L. Edwards, The Elusive Dream: The Power of Race in Interracial Churches (New York: Oxford University Press, 2008), 124; David R. Roediger, The Wages of Whiteness: Race and the Making of the American Working Class (New York: Verso, 1991), 133-56.

11. Maurice Jackson, "'Friends of the Negro! Fly with me, The path is open to the sea': Remembering the Haitian Revolution in the History, Music, and Culture of the African American People," Early American Studies 6, no. 1 (Spring 2008): 69-71. Blacks also contributed to racial theory in the early United States; see Bruce Dain, A Hideous Monster of the Mind: American Race Theory in the Early Republic (Cambridge: Harvard University Press, 2002). Nonwhite views on race are often less well understood than racial hegemonies; see David A. Chang, The Color of the Land: Race, Nation, and the Politics of Landownership in Oklahoma, 1832-1929 (Chapel Hill: University of North Carolina Press, 2010), 6-8.

12. Alida Metcalf, Go-betweens and the Colonization of Brazil, 1500-1600 (Austin: University of Texas Press, 2005), 10-12, 158, 193. Julius C. Scott, "The Common Wind: Currents of Afro-American Communication in the Era of the Haitian Revolution" (Ph.D. diss., Duke University, 1986), 5. Paul Gilroy, The Black Atlantic: Modernity and Double Consciousness (Cambridge: Harvard University Press, 1993), 12-13.

13. "Moral Qualities of the Negro," Colored American, March 25, 1837, 1. "England," Freedom's Journal, November 9, 1827, 2. "Movements of Free People of Color," Colored American, June 5, 1841, 1. "Western Africa," Freedom's Journal, June 20, 1828, 4. "The West Indies," Colored American, July 14, 1838, 1. "World's Convention," Colored American, April 18, 1840, 2. "Hayti," Colored American, April 12, 1838, 2. "Hayti," Freedom's Journal, December 12, 1828, 3. 
Declaration of Independence and the Constitution, drawn sustenance from British abolitionism, or conjured a lost, bucolic African past, the early black press selected Haiti as a wholly alternative model within the Black Atlantic. ${ }^{14}$

This was a considerable break from the pan-African identity and kinship discourses that had developed among U.S. black intellectuals, writers, clergy, and abolitionists from roughly 1750 onward. Such ties were shaped by blacks in the United States during the eighteenth and early nineteenth centuries to root, authenticate, and dignify their community through a conceptual relationship with an idealized African continent, a shared experience of becoming "African" through slavery and racial oppression in the Americas, and a neglect of specific ethnicities within the actual African diaspora. This essentialist, redemptive ingredient to U.S. black identity was one thread in a tapestry of broader identifications. Inherited affiliations within the Black Atlantic, a space of heterogeneous meaning and inspiration first

14. Thelma Wills Foote, Black and White Manhattan: The History of Racial Formation (New York: Oxford University Press, 2004), 125-39, 226-33. Edward Bartlett Rugemer, The Problem of Emancipation: The Caribbean Roots of the American Civil War (Baton Rouge: Louisiana State University Press, 2008), 17, 239. Peter Linebaugh and Marcus Rediker, The Many-Headed Hydra: Sailors, Slaves, Commoners, and the Hidden History of the Revolutionary Atlantic (Boston: Beacon Press, 2000), 174-210. Jill Lepore, New York Burning: Liberty, Slavery, and Conspiracy in Eighteenth-Century Manhattan (New York: Knopf, 2005), 54-56. Carla L. Peterson, "Remembering the Past, Inventing the Future: Black Family and Community in Nineteenth-Century New York City," in Joanne M. Braxton and Maria Diedrich, eds., Monuments of the Black Atlantic: Slavery and Memory (Münster: LIT Verlag, 2004), 101-16. Harris, In the Shadow of Slavery, 3. Scott Hancock, "From 'No Country!' to 'Our Country!': Living Out Manumission and the Boundaries of Rights and Citizenship, 1773-1855," in Rosemary Brana-Shute and Randy J. Sparks, eds., Paths to Freedom: Manumission in the Atlantic World (Columbia: University of South Carolina Press, 2009), 274-75. R. J. M. Blackett, Building an Antislavery Wall: Black Americans in the Atlantic Abolitionist Movement (Baton Rouge: Louisiana State University Press, 1983). Benjamin Quarles, Black Abolitionists (New York: Oxford University Press, 1969), 117-19. Ashli White, Encountering Revolution: Haiti and the Making of the Early Republic (Baltimore: Johns Hopkins University Press, 2010). Matthew Clavin, Toussaint L'Ouverture and the American Civil War: The Promise and Peril of a Second Haitian Revolution (Philadelphia: University of Pennsylvania Press, 2010). The phrase "uses of Haiti" is a tribute to the work of Paul Farmer, though I use the phrase very differently; see Paul Farmer, The Uses of Haiti (Monroe, Maine: Common Courage Press, 1994). Margaret MacMillan, The Uses and Abuses of History (London: Profile Books, 2009). Benedict Anderson, Imagined Communities: Reflections on the Origins and Spread of Nationalism (London: Verso, 1991). 
fused by common racialized degradations in European colonialism, also influenced their struggles over civic inclusivity amid the liberal and emancipatory trends of the national era. ${ }^{15}$

These pan-African discourses faded from favor by the 1820s owing to a growing perceived pejorative tinge to the "African" appellation, including use by whites to imply that African descendants belonged on the African continent and deserved no place in the Americas. Some scholars have recently asserted that this shift signaled a move away from broader collective identity, and that thereafter solely formalist demands for equality, divorced from rhetoric of racial redemption, coalesced their action. Though a panAfrican identity substantially subsided, a Black Atlantic engagement did not. Some have also speculated that a nascent black nationalist separatism tied to the example of Haiti developed in the first two decades of the nineteenth century. An incipient black nationalist sentiment may have inspired some black emigrants, but this use of Haiti was relatively absent from the early black press. ${ }^{16} \mathrm{My}$ proposition is that the black press of New York City, as a voice of its community, advocated for egalitarian inclusion and radical republicanism, using Haiti's revolution as a menacing precedent toward abolition, and its republic as a redemptive model of black citizenship, self-rule, civic responsibility, and cultural refinement for replication in the United States.

Scholars have rapidly rediscovered the importance of Haiti to African descendants in the Americas - and rightly so, as it was a critical but longunderestimated catalyst. ${ }^{17}$ Extant scholarship, however, largely does not

15. Douglas B. Chambers, "The Black Atlantic: Theory, Method, and Practice," in Toyin Falola and Kevin D. Roberts, eds., The Atlantic World, 1450-2000 (Bloomington: Indiana University Press, 2008), 151-73.

16. James Sidbury, Becoming African in America: Race and Nation in the Early Black Atlantic (New York: Oxford University Press, 2007), 6-15, 181-202. Sara C. Fanning, "The Roots of Early Black Nationalism: Northern African Americans' Invocations of Haiti in the Early Nineteenth Century," Slavery and Abolition 28, no. 1 (April 2007): 61-85. Sara C. Fanning, "Haiti and the U.S.: African American Emigration and the Recognition Debate" (Ph.D. diss., University of Texas-Austin, 2008), 75-76, 82-83. Some view $1827-60$ as a period of growth in African association for black New Yorkers; for an example see Hodges, Root E Branch, 224-25. Ariela Gross, What Blood Won't Tell: A History of Race on Trial in America (Cambridge: Harvard University Press, 2008), 182-99. Quarles, Black Abolitionists, 6-7. Bacon, First African-American Newspaper, 18, 108, 116-17.

17. David P. Geggus, ed., The Impact of the Haitian Revolution in the Atlantic World (Columbia: University of South Carolina Press, 2001). Maurice Jackson and Jacqueline Bacon, eds., African Americans and the Haitian Revolution: Selected Essays and Historical Documents (New York: Routledge, 2010). Léon Dénius Pamphile, 
contextualize these negotiations of Haiti within the broader Black Atlantic, nor does it trace preceding or concomitant transnational links, transcend the confines of the nation-state as an analytical lens, or contrast representations of Haiti with the actual contours of its history. Scholars have recuperated narratives on the Haitian Revolution's importance, but often without demonstrating change over time in the symbolism of Haiti, or its complex relationship with the reshaping of pliable racial identities in this historical moment. Moreover, the two discrete yet complementary facets of the Haitian example, those of the revolution and of the republic, have largely been conflated in scholarship on both U.S. blacks and the broader Black Atlantic, despite their divergent significations. ${ }^{18}$

I seek to complement this earlier scholarship by illuminating the unexplored racial project of free blacks and their ambition for inclusion in their homeland. As pan-African concepts waned, racial formation became centered on the varied uses of the Haitian Revolution and the Republic of Haiti. This is visible in both newspapers that arose from the black community of New York City, whereas previous scholars have privileged coverage of Freedom's Journal largely because of its status as the first black newspaper in the United States. ${ }^{19}$ These two newspapers bridged the transition from pan-Africanism and a romanticized Old World toward a Black Atlantic connectivity centered on the Americas and blacks' collective fixity therein. Sharp attention to these two print venues brings into focus the evolution of racial identity.

The analytical device of racial formation offers a valuable explanatory tool for studying the malleability of racial identities through structural and

Haitians and African Americans: A Heritage of Tragedy and Hope (Gainesville: University Press of Florida, 2001). Philip Edmondson, “To Plead Our Own Cause': The St. Domingue Legacy and the Rise of the Black Press," Prospects 29 (October 2005): 121-54. Dennis Hidalgo, "From North America to Hispaniola: First Free Black Emigration and Settlement in Haiti (Hispaniola)" (Ph.D. diss., Central Michigan University, 2001). Eric Foner, Nothing but Freedom: Emancipation and Its Legacy (Baton Rouge: Louisiana State University Press, 2007), 39-73.

18. Peterson, "Remembering the Past, Inventing the Future," 103. Harris, In the Shadow of Slavery, 43, 73, 238. Jack P. Greene, "Beyond Power: Paradigm Subversion and Reformulation and the Re-creation of the Early Modern Atlantic World," in Darlene Clark Hine and Jacqueline McLeod, eds., Crossing Boundaries: Comparative History of Black People in Diaspora (Bloomington: Indiana University Press, 1999), 319-42. Foote, Black and White Manhattan.

19. Bacon, First African-American Newspaper. Jacqueline Bacon, "The History of Freedom's Journal: A Study in Empowerment and Community," Journal of African American History 88, no. 1 (Winter 2003): 1-20. 
discursive evolution. I employ the definition of a racial project as "simultaneously an interpretation, representation, or explanation of racial dynamics, and an effort to reorganize and redistribute resources along particular racial lines." Old, onerous classifications of race were challenged and dismantled. Racial categories were crafted or resignified and assumed with the objective of shifting discursive representation toward subverting racialized social stratification. As past conceptions of racial degradation had themselves evolved in the service of hegemonic needs, new translocal elements constituted counterhegemonic solutions, as the early black press discursively deployed a reimagined Haiti as a Black Atlantic solution to their local and national problems. ${ }^{20}$

During the runs of these newspapers abolition occurred in New York state in 1827 and the British Empire liberated its slaves in 1834, and throughout this era new republics of the Americas began to announce emancipation. They imagined themselves within a broader community of colaborers in a struggle for rights that extended far beyond the United States. Despite heartily endorsing these dramatic developments, the newspapers habitually centered Haiti as their salient point of mobilization, rendering these constructions most intelligible within a Black Atlantic framework of oppression and resistance. As their own webs of identity creation surpassed borders, it is incumbent on scholars to follow these meanings beyond parochial parameters to understand the intertwined use of Haiti and evolving racial identification in the early U.S. republic.

\section{COMMON VISION, SUSTAINED REVISION, SHARED COMMUNITY}

Freedom's Journal and the Colored American, combined with their respective short-lived antecedent and subsequent newspapers-the Rights of All and

20. Omi and Winant, Racial Formation, 55-61. Originally developed to discuss twentieth-century race in the United States, this model of racial formation has since been efficaciously applied to a plethora of venues and is useful for explaining Haiti's function to identity construction in the early black press. See Foote, Black and White Manhattan, 1-7, 242-43; Sturm, Blood Politics, 20-22; Antonio T. Tiongson Jr., Edgardo V. Gutierrez, and Ricardo V. Gutierrez, Positively No Filipinos Allowed: Building Communities and Discourse (Philadelphia: Temple University Press, 2006), 53; Martha Menchaca, Recovering History, Constructing Race: The Indian, Black, and White Roots of Mexican Americans (Austin: University of Texas Press, 2001); Leith Mullings, "Interrogating Racism: Toward an Antiracist Anthropology," Annual Review of Anthropology 34, no. 1 (October 2005): 672. U.S. black abolitionists in this era were increasingly enlivened by connections with abolitionist Britons. See Quarles, Black Abolitionists; Blackett, Building an Antislavery Wall; Jane H. Pease and William H. Pease, They Who Would Be Free: Blacks' Search for Freedom, 18301861 (New York: Atheneum, 1974). 
the Weekly Advocate-were two of the longest-running and most widely circulated black newspapers in the antebellum United States. Freedom's Journal ran from 1827 to 1829 and circulated roughly eight hundred newspapers each week, which equaled subscription totals of the mainstream presses in New York City. ${ }^{21}$ The Colored American was published from 1837 until 1841. At its zenith it filled an impressive two thousand subscriptions. ${ }^{22}$ The newspapers collectively circulated very widely, including places such as Michigan, Maine, North Carolina, Rhode Island, Maryland, Massachusetts, Washington, D.C., Connecticut, Pennsylvania, Ohio, New Jersey, Virginia, Canada, Britain, Jamaica, and Haiti. ${ }^{23}$ The number of eyes perusing the pages of these newspapers, and of ears hearing their words read aloud, gave these writers a substantial audience both in New York City's black community and across the Atlantic. ${ }^{24}$

The scope of source material for the newspapers ranged from regular and special correspondence to news from ship crews, local, national, and international newspapers, pamphlets, and sundry books. Reprints were not uncommon..$^{25}$ But the sifting, selection, intercession, and projection of the editors in using Haiti was their own, which along with original stories complemented their polemics against discrimination in the remaking of their identity.

On March 16, 1827, Freedom's Journal was founded by free black activists in New York City, from which two colleagues, John Russwurm and Samuel Cornish, were selected by their peers to found the newspaper. They sought to plead their community's own cause, asserting that for too long others had spoken for them. Cornish and Russwurm cited the proliferation of false-

21. Bacon, First African-American Newspaper, 51.

22. "Our Noble Committee," Colored American, April 12, 1838, 2.

23. "Jamaica, West Indies," Colored American, August 1, 1840, 2. "General Agency," Colored American, April 1, 1837, 3. "Notice, Our Agents," Colored American, September 8, 1838, 3. Charles A. Ray, "New Agencies," Colored American, November 11, 1837, 3. Bacon, First African-American Nerwspaper, 53.

24. Sibylle Fischer, Modernity Disavowed: Haiti and the Cultures of Slavery in the Age of Revolutions (Durham: Duke University Press, 2004), 35-37. Gilroy, Black Atlantic, 7.

25. Bacon, First African-American Newspaper, 124, 149. Freedom's Journal used coverage from the Genius of Universal Emancipation of Baltimore, the Abolition Intelligencer of Kentucky, London's Quarterly Review, and Le Télégraphe and Feuille $d u$ Commerce of Haiti, among others. The Colored American often used Jamaica's Morning Journal, the Feuille du Commerce, and British Emancipator, among others. The editors commonly exchanged letters with correspondents, friends, and abolition societies abroad, particularly those in Haiti, Jamaica, and Britain. 
hoods and exaggerations about their community that "tends to the discredit of any person of colour" as another reason for establishing the newspaper. ${ }^{26}$ Though Freedom's Journal emphasized Haiti in its racial project, one of its two editors, John Russwurm, in fact supported colonization, and some waning pan-Africanism still appeared in its pages. Furthermore, the Haitian Revolution's emancipatory furor garnered more attention in Freedom's Journal than in the Colored American. This may be attributed to the recent debates over slavery in New York State, where abolition occurred in 1827 after years of gradual emancipation laws. ${ }^{27}$ The Colored American, then, was a more principal venue for the rejection of a pan-African identity and colonization and the elevation of the overall importance of the Republic of Haiti to the goals of inclusion of U.S. blacks.

Following statewide abolition, when material coercions against blacks in New York relaxed, whites' codified social elevation was challenged. Bigotry increased to compensate for this threat and to cauterize a vulnerable racial hierarchy. Immediate cases of such racist misinformation cited by the editors included malignant writings against blacks in the New York Enquirer and New York Evening Post, which spoke of free blacks as an "abominable nuisance," referred to black women as inherently lascivious, and virulently defended slavery, among other inflammatory assertions. These caustic local newspapers were early targets of Freedom's Journal. Cornish and Russwurm resorted to "forcible argument" to confront their enemies, and they identified disseminating positive news about people of African descent as a way to elevate their community to respectability. ${ }^{28}$ The editors evinced this goal by using the inequitable cultural medium of the newspaper to assert their counternarrative.

26. Cornish and Russwurm, "To Our Patrons," 1. Simmons, The African American Press, 9-10. Bacon, First African-American Newspaper, 1.

27. Gellman, Emancipating New York, 189-219. Christopher Tomlins, Freedom Bound: Law, Labor, and Civic Identity in Colonizing English America, 1580-1865 (New York: Cambridge University Press, 2010), 505. Winston James, The Struggles of John Brown Russwurm: The Life and Writings of a Pan-Africanist Pioneer, 17991851 (New York: New York University Press, 2010), 2-3, 30, 108. Bacon, First African-American Newspaper, 116-17, 165. Sidbury, Becoming African, 181-202. Hodges, Root \& Branch, 225-26.

28. "Case of Gilbert Horton," Freedom's Journal, March 16, 1827, 2. "Slavery in the West Indies," Freedom's Journal, May 11, 1827, 2. "Major Noah's Negroes," Freedom's Journal, August 24, 1827, 3. Simmons, The African American Press, 9-10. Samuel Cornish and John Russwurm, "Prospectus," Freedom's Journal, March 23, 1827, 4. Hodges, Root \& Branch, 227-28. 
The editors' lives had afforded them a capacious exposure to the world, a vantage through which they contextualized their oppression and planned for its redress. John Russwurm was born in 1799 to a white merchant father and a black mother in Port Antonio, Jamaica. At age eight John was sent to Quebec for schooling, and in 1826 he earned a bachelor's degree from Bowdoin College, becoming one of the first black college graduates in the United States. At Bowdoin he gave the commencement address, in which he extolled the promise and achievements of Haiti, where he intended as late as 1826 to emigrate. ${ }^{29}$ Samuel Cornish was born to free black parents in Delaware in 1795. He attended Princeton Seminary, and in 1821 he helped found the first black Presbyterian church in New York City. Though this editorial duo split some months after launching Freedom's Journal, Cornish collaborated throughout the newspaper's run. When Freedom's Journal faltered with Russwurm's emigration to Liberia in 1829, Cornish resumed its publication under the name Rights of All, which ran through 1830. There was no black newspaper in New York City again until Cornish and his colleagues Charles Ray and Philip Bell pioneered the Weekly Advocate, which was promptly renamed the Colored American. ${ }^{30}$

Amid the tumult surrounding the American Colonization Society's push to move blacks from the United States to the Liberia colony, free blacks in the U.S. North especially came to question the sobriquet African as an ingredient of their identity. They thought that this term, and African American, destabilized their legitimacy as rightful native denizens in the Americas. This lent those they perceived as white, racist colonizationists the terminology to affiliate them with, and displace them to, Africa. The Colored American was so named to connote a permanence in the New World, and it rejected African and negro monikers along with other terms that they deemed to be derogatory or marginalizing. The Colored American, then,

29. James, The Struggles of John Brown Russwurm, 5-25. Armistead Pride and Clint Wilson, A History of the Black Press (Washington, D.C.: Howard University Press, 1997), 12. John B. Russwurm "The Condition and Prospect of Hayti," commencement address (1826), reprinted in Journal of Negro History 54, no. 4 (October 1969): 395-97. James, The Struggles of John Brown Russwurm, 19.

30. Julie Winch, ed., The Elite of Our People: Joseph Willson's Sketches of Black Upper-Class Life in Antebellum Philadelphia (University Park: Pennsylvania State University Press, 2000), 134-37. Patrick Washburn, The African American Nerwspaper: Voice of Freedom (Evanston, Ill.: Northwestern University Press, 2006), 17-18. Bacon, First African-American Newspaper, 54-56. Pride and Wilson, Black Press, 12. Juan González and Joseph Torres, News for All the People: The Epic Story of Race and the American Media (London: Verso, 2011), 109-25. 
blazed a trail for positively resignifying the colored category and forging a plural American identity. ${ }^{31}$

Cornish, Ray, and Bell had all served as delegates to the first National Negro Convention in Philadelphia in 1830. Around that time they also collaborated in the local black temperance movement. Bell was born free in New York City in 1808 and had grown up within its free black activist community, attending the city's African Free School, where, at times, Russwurm taught and for which Cornish solicited students. They also collaborated with the African Society for Mutual Relief. Bell and Cornish later eulogized William Wilberforce together at a public service in 1833. Ray was a latecomer to New York City. He was born free in Falmouth, Massachusetts, and after being rejected by Wesleyan University because of his race, in 1830 he moved to New York City and opened a shoe shop. Shortly thereafter he joined the American Anti-Slavery Society and the New York Vigilance Committee, in which Cornish and Bell served, and was ordained a Methodist minister in $1834 .{ }^{32}$

In the period between the closing of Freedom's Journal and founding of the Colored American, the terrain of abolitionism in the United States changed. Some high-profile white abolitionists, such as William Lloyd Garrison, had become immediatists toward emancipation. By 1841 and the end of the Colored American the American Anti-Slavery Society had been

31. "Colored People Always Opposed to Colonization," Colored American, May 13, 1837, 2. Sidbury, Becoming African, 13-14, 181-202. Bacon, First AfricanAmerican Nerwspaper, 269. “A Point Settled," Colored American, February 16, 1839, 3. Elizabeth McHenry, Forgotten Readers: Recovering the Lost History of African American Literary Societies (Durham: Duke University Press, 2002), 107-9. Harris, In the Shadow of Slavery, 134.

32. Howard Holman Bell, ed., Minutes of the Proceedings of the National Negro Conventions (New York: Arno Press, 1969), 11-23. González and Torres, News for All the People, 109-25. Quarles, Black Abolitionists, 95. Harris, In the Shadow of Slavery, 126, 181. Leslie M. Alexander, African or American? Black Identity and Political Activism in New York City, 1784-1861 (Urbana: University of Illinois Press, 2008), 208. James, The Struggles of John Brown Russwurm, 43, 47, 55, 269. "African Free Schools," Freedom's Journal, April 4, 1828, 8. Charles C. Andrews, The History of the New-York African Free-Schools (New York: Mahlon Day, 1830), 34, 69. Benjamin F. Hughes, Eulogium on the Life and Character of William Wilberforce, Esq. (New York: Office of the Emancipator, 1833), 3. Milton C. Sernett, ed., African American Religious History: A Documentary Witness, 2nd ed. (Durham: Duke University Press, 1999), 218. Hodges, Root E Branch, 245-48. First Annual Report of the American Anti-Slavery Society (New York: Door \& Butterfield, 1834), 34-35. First Annual Report of the New York Committee of Vigilance (New York: Piercy \& Reed, 1837), 83. 
splintered by pro- and anti-Garrison factions. The black press of New York City was always immediatist, however, and its use of Haiti was certainly not disrupted by national partisanship and ideological squabbles. Even the violent Nat Turner Rebellion of 1831 in Virginia, which further terrified whites of black radicalism and elicited paranoid and draconian responses against perceived black organizing, did not deter the Colored American from using images of Haiti for its needs. ${ }^{33}$

Despite a lapse of years and these notable events having transpired between the operation of two newspapers, the community from which these projects arose had changed little, and its members' original concerns had not been ameliorated. This black activist community was overwhelmingly freeborn in the North, educated, middle-class, religiously connected, and part of an interlaced network of abolitionist, civil rights, and church organizations. After a series of national black rights conventions in which Cornish and his colleagues found themselves somewhat alienated from the wealthier, racially appeasing, and less politically minded free blacks of Philadelphia, the New York activists were reinvigorated to operate a black press. The Colored American largely began where Freedom's Journal had left off. Some names changed, though their nucleus was tight-knit, considering the many thousands of blacks living in New York City in this era. ${ }^{34}$ They were not always in agreement, but the editors and the larger black activist community of New York City did not question the importance of Haiti to their racial rehabilitation project, using it to counter the five common sites of racial attacks on blacks, namely, intellect, prosperity, health, self-rule, and morality. ${ }^{35}$

33. Dexter B. Gordon, Black Identity: Rhetoric, Ideology, and Nineteenth-Century Black Nationalism (Carbondale: Southern Illinois University Press, 2006), 73-77. Michael P. Young, "A Revolution of the Soul: Transformative Experiences and Immediate Abolition," in Jeff Goodwin, James Jasper, and Francesca Polletta, eds., Emotions, Politics, and Social Movements (Chicago: University of Chicago Press, 2001), 99-114. John Stauffer, The Black Hearts of Men: Radical Abolitionists and the Transformation of Race (Cambridge: Harvard University Press, 2001), 98, 252-54.

34. There were over 10,000 free blacks in New York City by 1820; see Harris, In the Shadow of Slavery, 117. There were over 16,000 blacks living in New York City by 1840; see Hodges, Root E Branch, 230.

35. Graham Russell Hodges, David Ruggles: A Radical Black Abolitionist and the Underground Railroad in New York City (Chapel Hill: University of North Carolina Press, 2010), 37-44, 143-52. Hodges, Root E Branch, 199-200. Sterling Stuckey, Slave Culture: Nationalist Theory and the Foundations of Black America (New York: Oxford University Press, 1987), 208-10. James Oliver Horton and Lois E. Horton, 
The colored nomenclature was not the only concept in need of resignification, as the use of Haiti by the black community was itself a complex proposition. Before the Haitian Revolution, the U.S. South had at least entertained gradual emancipation and questions over slavery's longevity. The revolution contributed to a halt to such discussions, as it represented terrifying images of irrational vengeance and usurpation in the minds of many U.S. whites. Though Haiti was a causative factor for ending the U.S. slave trade, it also hardened slaveholders against abolition. Its postemancipation hardships were frequently cited as evidence of black incapability for self-maintenance in proslavery arguments, and the Denmark Vesey conspiracy of 1822 in South Carolina was a reminder of Haiti's near ubiquitous effect on black resistance. ${ }^{36}$

This mixed and polarizing baggage similarly inspired and horrified observers throughout the Atlantic world, and it certainly divided U.S. abolitionists on its appropriate use as an object lesson. Some colleagues of the editors, such as David Walker and Henry Highland Garnet, espoused selfemancipation. Freedom's Journal used it as a threat. They all justified what they saw as the righteous, exemplary violence of the Haitian Revolution, though these were minority opinions within black abolitionism. ${ }^{37}$ The less

In Hope of Liberty: Culture, Community, and Protest among Northern Free Blacks, 1700-1860 (New York: Oxford University Press, 1998), 201-2. David E. Swift, Black Prophets of Justice: Activist Clergy before the Civil War (Baton Rouge: Louisiana State University Press, 1989), 56-57, 82. R. J. Young, Antebellum Black Activists: Race, Gender, and Self (New York: Garland, 1996), 25-26. Harris, In the Shadow of Slavery, 203-6.

36. Ashli White, "The Limits of Fear: The Saint-Dominguan Challenge to Slave Trade Abolition in the United States," Early American Studies 2, no. 2 (Fall 2004): 362-97. Alfred N. Hunt, Haiti's Influence on Antebellum America: Slumbering Volcano in the Caribbean (Baton Rouge: Louisiana State University Press, 1988), 1-5, 146-52. Elizabeth Fox-Genovese and Eugene D. Genovese, The Mind of the Master Class: History and Faith in the Southern Slaveholders' Worldview (New York: Cambridge University Press, 2005), 14-39. Dain, A Hideous Monster, 90-91. Clavin, Toussaint L'Ouverture, 5, 58. George M. Frederickson, The Black Image in the White Mind: The Debate on Afro-American Character and Destiny, 1817-1914 (Middletown, Conn.: Wesleyan University Press, 1987), 9, 54, 259.

37. Hunt, Haiti's Influence, 147-51. White, Encountering Revolution, 134-37. Srividhya Swaminathan, Debating the Slave Trade: Rhetoric of British National Identity, 1759-1815 (Burlington, Vt.: Ashgate, 2009), 28-29. Malick W. Chachem, The Old Regime and the Haitian Revolution (New York: Cambridge University Press, 2012), 303-13. See the essays by David Brion Davis, Seymour Drescher, and Robin Blackburn in "Part One: Overview," in Geggus, The Impact of the Haitian Revolu- 
acerbic tack of the Colored American was tempered by new impetuses. Its moderation came in the wake of the Nat Turner Rebellion, increased U.S. sectionalism, the tapering of abolition debates in the region, and full rejection of colonization. Revolutionary talk had been further stigmatized, as local political concerns confronted civil rights struggles. The threat of race war was also less relevant without a desire for separatism. The shift of interest toward permanence and inclusion partly explains why colonization faded in this period. In any case, before the Haitian Revolution could exemplify black self-determination by the oppressed in the Americas, and before the Republic of Haiti could serve as a specific model for black citizenship and support an alternative identity to the amalgamate "African" discourse, both newspapers had to recast and restore Haiti. ${ }^{38}$

\section{RACIAL FORMATION AND HAITIAN REVOLUTION REIMAGINED: FREEDOM'S JOURNAL}

Haiti was a key feature in Freedom's Journal from its inception, as the editors tied the newspaper's purposes and target audience to its legacy. Soon after its founding the newspaper launched several lengthy series on Haiti, including six articles on the nation's formation, a five-part series on Henri Christophe's widow, and a lengthy biography of Toussaint L'Ouverture. Other early mentions of Haiti included calls for official U.S. recognition and stories of fugitive U.S. slaves making their way to Haiti to take advantage of its free-soil protections. ${ }^{39}$

tion in the Atlantic World, 3-22. Matthew J. Clavin, "Race, Revolution, and the Sublime: The Gothicization of the Haitian Revolution in the New Republic and Atlantic World," Early American Studies 5, no. 1 (Spring 2007): 1-29. Bacon, First African-American Newspaper, 127.

38. Stuckey, Slave Culture, 128. Chris Dixon, African America and Haiti: Emigration and Black Nationalism in the Nineteenth Century (Westport, Conn.: Greenwood Press, 2000), 29, 46-50. Ada Ferrer, "Haiti, Free Soil, and Antislavery in the Revolutionary Atlantic," American Historical Review 117, no. 1 (February 2012): 40-66. The Haitian Revolution and the Republic of Haiti were much more than subtexts to New York City's early black press, and they did in fact serve as their epitome of black society. See Dain, A Hideous Monster, 111; Dickson D. Bruce, The Origins of African American Literature, 1680-1865 (Charlottesville: University Press of Virginia, 2001), 120-21.

39. "Hayti" (nos. I-VI), Freedom's Journal, April 20-October 12, 1827. "Foreign News," Freedom's Journal, April 27, 1827, 3. "Madame Christophe," Freedom's Journal, May 11-July 11, 1827. "By a Late Arrival from Port-au-Prince," Freedom's Journal, March 16, 1827, 3. "People of Colour," Freedom's Journal, April 13, 1827, 1. Ferrer, "Haiti, Free Soil, and Antislavery in the Revolutionary Atlantic." 
Wading through the violent connotations of the revolt, the newspaper quickly indicted the cruelty of French planters as the fuse for violent insurrection. ${ }^{40}$ To the editors, the revolution was a just war fueled by righteous anger. Overall, Freedom's Journal expended twice as much ink as the Colored American would on the revolution specifically. In this coverage the violence and heroism of the slave insurgents and their leaders were more openly applauded. This even included apologetic coverage of Jean-Jacques Dessalines, L'Ouverture's right-hand man and the eventual first head of the Haitian state. Dessalines was viewed by U.S. whites as a bloodthirsty maniac and architect of a race war. Yet in the few words Freedom's Journal spent on Dessalines he was depicted as a defender of black rights and protector against reenslavement who had no choice but to use violence. ${ }^{41}$ The editors portrayed L'Ouverture, Dessalines, and Christophe as dutiful, noble soldiers, not the marauding, murderous, rogue slaves of white perception.

In a six-part series of articles on Haiti the editors chose to draw out certain inspirations from the Haitian Revolution, noting that the "unnatural connexion of master and slave" was torn apart by the "irresistible course of events" through which all people who have been deprived of liberty would regain it. ${ }^{42}$ Not only was emancipation asserted as an eventuality, but the veiled threat of possible slave revolution was issued to advocates of slavery. It also read, "I trust also, that the lesson inculcated by Haitiens, will be a warning where man is held in bondage and degradation by his fellowwhenever he is denied the unalienable rights of nature. It will teach petty despots, that in oppression, the chain has a certain length." ${ }^{43}$ The newspaper further warned oppressors that "the time of their trial is drawing near." ${ }^{44}$ Similar ideas of emancipatory struggle emanated from this free black community, including those from the Freedom's Journal affiliate David Walker and his Appeal, published in 1829, and in the writings of Robert Alexander Young. Walker, a subscription agent and writer for Freedom's Journal based primarily in Boston, also promoted the example of Haiti as a model for black liberation in his watershed revolutionary writings. ${ }^{45}$ Since not all states

40. "People of Colour," Freedom's Journal, April 27, 1827, 1.

41. “Toussaint L'Ouverture,” Freedom's Journal, May 18, 1827, 1. Dain, A Hideous Monster, 90.

42. "Hayti, No. II," Freedom's Journal, April 27, 1827, 2.

43. "Hayti.-No. VI," Freedom's Journal, October 12, 1827, 2.

44. "Slavery," Freedom's Journal, November 30, 1827, 3.

45. "At a Respectable Meeting of the People of Colour," Freedom's Journal, March 16, 1827, 3. Sterling Stuckey, Ideological Origins of Black Nationalism (Boston: Beacon Press, 1972), 168-70. Stuckey, Slave Culture, 128. Bacon, First AfricanAmerican Newspaper, 260. Peter P. Hinks, To Awaken My Afflicted Brethren: David 
in the region had abolished slavery and free black citizenship was precarious, both of which fed separatism and colonization, the Haitian Revolution appealed to segments of northern blacks as a militant beacon. ${ }^{46}$

The Haitian Revolution had in fact driven scores of white SaintDominguan families, and their slaves, to New York City. For years these émigrés antagonized the city's polarized political and racial milieu. Many local whites, such as John Jay, sought funds for the refugees, who generally praised their hosts, whereas the émigrés' slaves attempted to return home or sought legal redress in U.S. courts. In 1801 a cruel French owner tried to send her slaves to Virginia unlawfully, which prompted a large protest by armed slaves, led by Saint-Dominguans, to stop her. These events shaped immediate racial contexts and local continuities of the Haitian Revolution's influence, yet the editors chose to look further afield for their own meanings. Intriguingly, neither Freedom's Journal nor the Colored American dealt with the refugees, their legacies, or circumstances that preoccupied the preceding generation's engagement with Haiti. ${ }^{47}$

Other representations of Haiti illuminate how the editors saw themselves and their cadre of activists. Their description of the start of the Haitian Revolution held aloft the significance of the free colored population, who were primarily of mixed ancestry, exemplified by Vincent Ogé and Julien Raimond. These dissidents used a "war of words" to advocate for their own rights in the colony, by means of the promises enumerated by the French

Walker and the Problem of Antebellum Slave Resistance (University Park: Pennsylvania State University Press, 1997), 74-74, 100-101, 191. Hodges, Root E Branch, 244-45.

46. Harris, In the Shadow of Slavery, 116-19. Hodges, Root E Branch, 227-30. Alexander, African or American? 36-54. Patrick Rael, Black Identity and Black Protest in the Antebellum North (Chapel Hill: University of North Carolina Press, 2002), 223-26. Cedrick May, Evangelism and Resistance in the Black Atlantic, 1760-1835 (Athens: University of Georgia Press, 2008), 85-95. Rita Roberts, Evangelicalism and the Politics of Reform in Northern Black Thought, 1776-1863 (Baton Rouge: Louisiana State University Press, 2010), 173-75.

47. White, Encountering Revolution, 36, 62-64, 77-78, 145-46, 164, 179, 195. Sue Peabody, “'Free upon Higher Ground': Saint-Domingue Slaves' Suits for Freedom in U.S. Courts, 1792-1830," and Alyssa Goldstein Sepinwall, “The Specter of Saint-Domingue: American and French Reactions to the Haitian Revolution," in David P. Geggus and Norman Fiering, eds., The World of the Haitian Revolution (Bloomington: Indiana University Press, 2009), 272-76, 317-38. For example, they apparently had no relationship with Pierre Toussaint, the prominent ex-slave from Saint-Domingue who was then a well-connected hairdresser in New York City; see Arthur Jones, Pierre Toussaint: A Biography (New York: Doubleday, 2003). 
Revolution. To the editors this discursive intervention precipitated an eventual amelioration of material conditions. ${ }^{48}$ Abnegating black agency, many U.S. defenders of slavery also blamed free colored agitators for radicalizing Saint-Domingue, and they were wary of this similar class in the United States. It is easy to see how the editors identified with this free, mixed-race, catalytic social layer tied to revolutionary incitement. Black activists like Cornish, who had earned middle-class status and were often cognizant of their own color privileges, increasingly saw themselves as the managers of racial uplift. Yet, whereas the free colored population of Haiti was applauded in this instance, the countless rifts between free coloreds and exslaves of solely African ancestry were omitted in the newspaper. ${ }^{49}$

Furthermore, Freedom's Journal never touched on the subject of Haiti's bitter internal division between the largely black Kingdom of Haiti in the North, under Henri Christophe, and the mulatto-lead Republic of Haiti to the south, under Alexandre Pétion and later Jean-Pierre Boyer. Nor was the civil war that produced this nearly fifteen-year split ever mentioned. ${ }^{50}$ Because of the wide circulation of knowledge about this strife, and given the editors' great attention to information on Haiti, it is certain that they knew the particulars of these internecine conflicts. ${ }^{51}$ Yet they deliberately chose to convey a more stable Haiti to their audience. As part of the palliative representation of the Black Republic, the leaders of Haiti were particularly celebrated, often via hagiographies. Stories exalting Toussaint L'Ouverture, Henri Christophe and Madame Christophe, and Jean-Pierre Boyer for their intellect, urbanity, and propriety were common, despite

48. "Hayti, No. III,” Freedom's Journal, May 4, 1827, 2. Jacqueline Bacon, “'A Revolution Unexampled in the History of Man': The Haitian Revolution in Freedom's Journal, 1827-1829, in Jackson and Bacon, African Americans and the Haitian Revolution, 81-91.

49. Dain, A Hideous Monster, 90. Harris, In the Shadow of Slavery, 120-25, 203-4. Philippe R. Girard, Paradise Lost: Haiti's Tumultuous Journey from Pearl of the Caribbean to Third World Hot Spot (New York: Palgrave Macmillan, 2005), 58-60. Pamphile, Haitians and African Americans, 192.

50. They vaguely mentioned the split once and said that the details were unnecessary. See "Hayti V," Freedom's Journal, June 29, 1827, 2. David Nicholls, From Dessalines to Duvalier: Race, Color, and National Independence in Haiti (New York: Cambridge University Press, 1979), 97-98. Girard, Paradise Lost, 61-64.

51. Dain, A Hideous Monster, 89-93. Laurent Dubois, Haiti: The Aftershocks of History (New York: Metropolitan Books, 2012), 56-67. Clavin, Toussaint L'Ouverture, 5, 58. Frederickson, Black Image, 9, 54, 259. Hunt, Haiti's Influence, 159-61. "Hayti V," Freedom's Journal, June 29, 1827, 2. 
these individuals' conflicting goals and legacies, their rivalries, and the civil strife they at times inflicted on Haiti itself. ${ }^{52}$

This probably exposes some ingredients fundamental to the editors' racial solidarity. While they may have viewed themselves as a vanguard for U.S. blacks, they had a sense of common struggle that transcended their mixedrace ancestry. Furthermore, it was critical for them to present the most polished models of black leaders to their readers, without muddying the waters with caveats or Haiti's own conflicts and stratifications. Accounts of how average Haitians' lives changed from slavery to freedom were basically absent in favor of the exceptional few, just as the activist editors of the black press were unrepresentative of those formerly enslaved. The editors subscribed to a great-man model of history, and, given their suspicion of popular politics in New York City, they perhaps aspired to such hierarchical importance as directors of the masses. ${ }^{53}$

By the editors' own admission they ventured to show Haiti as safe, as exceptionally peaceful, and as "the cradle of hope to future generations." ${ }_{4}$ Not only did they downplay internal discord among past leaders of Haiti, they also glossed over or denounced stories of popular unrest or criticism in the Republic of Haiti to maintain a placid image of the country on all fronts. The newspaper lauded the Haitian government, approving of its civility, civil rights, and stability. ${ }^{55}$ It also cast Haiti as one of the healthiest, most naturally abundant places on earth, calling it a "Garden of Eden," and

52. "Hayti," Freedom's Journal, February 14, 1829, 4. "Toussaint L'Ouverture," Freedom's Journal, May 4, 1827, 2. "Foreign News," Freedom's Journal, April 27, 1827, 3. "Madame Christophe," Freedom's Journal, May 11, 1827, 2. "Madame Christophe," Freedom's Journal, June 27, 1828, 2. "Madame Christophe," Freedom's Journal, July 4, 1828, 4. "Madame Christophe," Freedom's Journal, July 11, 1828, 4. The Toussaint serials were borrowed from London's Quarterly Review, and the limited coverage of him in the Colored American was drawn from the National AntiSlavery Standard and the James McCune Smith lectures. Pieces on the Christophe family were based on information largely from Boston's Columbian Centinel. Coverage of Boyer came from a mix of stories in various newspapers and letters.

53. Harris, In the Shadow of Slavery, 123-26. Joel Williamson, New People: Miscegenation and Mulattoes in the United States (New York: Free Press, 1980), 1-15.

54. "Volunteers," Freedom's Journal, October 24, 1828, 3. "Hayti," Freedom's Journal, December 12, 1828, 3.

55. "Conspiracy against the President of Hayti," Freedom's Journal, August 3, 1827, 3. "From Hayti," Freedom's Journal, June 13, 1828, 3. "Hayti," Freedom's Journal, August 8, 1828, 3. "Hayti," Freedom's Journal, December 12, 1828, 3. "Madame Christophe," Freedom's Journal, July 11, 1828, 4. "Hayti V," Freedom's Journal, June 29, 1827,2 . 
stated, "The Republic of Hayti exhibits ... that the descendants of Africa are capable of self-government: the plea so often urged by the adherents of slavery, 'the poor creatures, should we free them, will starve to death,' will now be but 'sounding brass' in the opinion of every reasonable man." ${ }^{56}$ And, citing the commercial possibilities of normalizing relations with Europe, the newspaper approved of Haiti's exorbitant and punitive indemnity it had agreed to pay to France for its own official diplomatic recognition and independence. ${ }^{57}$

The main talking points on black temperament vis-à-vis Haiti were again drawn from the revolutionary period and demonstrated through the biography of Toussaint L'Ouverture, which stated, "The negro character at that eventful period, burst upon us in all the splendor. ... And . . . have presented the most incontestible proofs, that the negro is not, in general, wanting in the higher qualifications of the mind." ${ }^{8}$ The editors assailed the notion that physical differences represented disparities in intellect or humanity, and that this supposed condition destined them to servitude. They believed that "the history of mankind not only contradicts but abundantly refutes this assumption." They articulated this point from evidence: "Toussaint Louverture ... was once a slave. He was a man of 'prodigious memory,' brave, active, indefatigable, and really great. . . Christophe, the late king of Hayti, arose from slavery to a throne." ${ }^{59}$ Their argument was that where "the Man of Colour" had been liberated from prejudices and given civil rights and citizenship, as in Haiti, he was equal to those of lighter skin and entirely capable. ${ }^{60}$

The introduction of the "colored" terminology here is provocative. This coverage painted aggressive emancipatory struggle as humanizing, the outcome being that where blacks were free their abilities were equal to whites', thereby meriting their civic inclusion. Their message was apologetic for radical abolition. It is clear, though, that Freedom's Journal was more interested in the Haitian Revolution as proof of self-possession and innate black dignity, and that the revolution's subsequent results of civility and prosperity helped justify its emancipatory violence.

With the apotheosis of Haiti firmly established in Freedom's Journal, John

56. “Hayti.-No. VI,” Freedom's Journal, October 12, 1827, 2.

57. "Mr. Hendricks," Freedom's Journal, September 21, 1827, 3.

58. “Toussaint L'Ouverture," Freedom's Journal, May 4, 1827, 2.

59. “The Surprising Influence of Prejudice," Freedom's Journal, May 18, 1827, 1.

60. "African Free Schools in the United States," Freedom's Journal, June 1, 1827,

3. "European Colonies in America," Freedom's Journal, July 13, 1827, 1. 
Russwurm, one of the dwindling few proponents of African colonization in New York City's free black community, departed the newspaper in 1829 to emigrate to the Liberia colony. Though sustaining Haiti as a preferred model, during its two-year run Freedom's Journal published roughly as many articles on Africa and colonization as the Colored American later would in four years. Freedom's Journal even published a five-part series on Paul Cuffe (or Cuffee), one of the last and greatest emblems of pan-Africanism and a pioneer of colonization in Liberia. ${ }^{61}$

The trajectory of Freedom's Journal is itself evidence that as pan-African interests waned, the significance of Haiti increased. This changing of the guard in the free black community of New York City, including Russwurm's symbolic exit, was emblematic of the larger shift of the northern black community away from pan-Africanism and toward the burgeoning use of Haiti as the Black Atlantic ideal alimenting their identity and ambitions. As the fractures over colonization mended, the presence of Haiti in this racial project was only amplified in importance within the pages of the Colored American, though its specific applications changed. As the conditions of abolitionism and civil rights battles evolved, these newspapers shifted the black community's discursive attachment to the Republic of Haiti. This example of black citizens, rooted firmly in the Americas and forged in struggle, became fixed as their central node of the Black Atlantic. ${ }^{62}$

\section{USES OF HAITI IN THE RACIAL PROJECT OF THE COLORED AMERICAN}

Though the Colored American began afresh in 1837, many of its adversaries were old. For example, the New York Courier E Enquirer, a "moral and political cancer" according to the Colored American's editors, was a frequent object of disdain for the new newspaper. ${ }^{63}$ The New York Courier \& Enquirer had been purchased from the former nemesis of Freedom's Journal,

61. See "Memoirs of Capt. Paul Cuffee," Freedom's Journal, March 16, 1827April 13, 1827. Lamont D. Thomas, Paul Cuffe: Black Entrepreneur and PanAfricanist (Urbana: University of Illinois Press, 1988). Sidbury, Becoming African, 157-80. Freedom's Journal and the Colored American each published about forty-six stories explicitly on Africa or Africans.

62. James, The Struggles of John Brown Russwurm, 200. Sidbury, Becoming African, 181-202.

63. "Foul Murder," Colored American, March 3, 1838, 3. "An American Citizen Murdered," Colored American, November 25, 1837, 2. David Ruggles, "Read This," Weekly Advocate, January 14, 1837, 2. "Col. R. M. Johnson," Colored American, June 29, 1839, 2. 
Mordecai Noah, and merged with another newspaper to become a Whig party mouthpiece. ${ }^{64}$ Prompted by integration of blacks into white spaces, such as a scandalous incursion by Cornish into segregated church seating, the mainstream newspapers published fulminations against the city's blacks in 1834. This stoked racial tensions and fueled a mob attack on abolitionists' and black leaders' homes and churches. ${ }^{65}$

As the black community was still openly slandered, the example of the Black Republic in the Colored American was used as a controversion, even as Haiti itself was being redefined and defended. ${ }^{66}$ At the time of the newspaper's founding, Cornish, Ray, and Bell were heavily involved in statewide activism for black suffrage. They traveled the state collecting petition signatures against the New York legislature's recent rejection of equal voting rights. This was one of several citizenship issues for which Haiti provided unique instruction as a republic, serving as a critical case study in the professed mission of the Colored American to seize "every means of reformation and improvement" to close their social disparities gap with whites. ${ }^{67}$

Some foes also emerged obliquely, like a wolf in sheep's clothing. This was the case with the American Colonization Society. Their disingenuous professions of assistance belied their aggressive exportation of blacks, whom they saw as unsuitable co-citizens. The Colored American stated that "no class of men, however pious and benevolent can take our place in the great work of redeeming our character and removing our disabilities." ${ }^{68}$ The editors stated very clearly that the purpose of the newspaper was to uplift their race in the Americas, writing, "It is nonsense to talk of . . . converting Africa to God, while we neglect her scattered sons among us, and trample on her poor at our doors." ${ }^{69}$ They declared, in the face of colonization

64. Hy B. Turner, When Giants Ruled: The Story of Park Row, New York's Great Newspaper Street (New York: Fordham University Press, 1999), 10-12. James Grant Wilson, The Memorial History of the City of New-York: From Its First Settlement to the Year 1892, Volume III (New York: New York History Co., 1893), 374-75.

65. Hodges, Root E Branch, 227-28. Swift, Black Prophets, 74-76.

66. "New York Courier and Enquirer," Colored American, May 8, 1841, 2.

67. "Responsibility of Colored People in the Free States," Colored American, March 4, 1837, 2. Quarles, Black Abolitionists, 171. Harris, In the Shadow of Slavery, 222. In their travels Bell and Ray tried to desegregate the dining cabin on a steamboat; see Hodges, Root E Branch, 248.

68. "Why We Should Have a Paper," Colored American, March 4, 1837, 2. Douglas C. Baynton, "Disability and the Justification of Inequality in American History," in Paul K. Longmore and Lauri Umansky, eds., The New Disability History: American Perspectives (New York: New York University Press, 2001), 33-58.

69. "Read the Following," Colored American, March 18, 1837, 3. 
schemes that proposed to send all blacks to Africa, "THIs is our Home." 70 And the use of the "Colored American" name moved beyond the "freedom" advocated in the title of its predecessor, Freedom's Journal, and claimed permanence and equal rights for blacks in the Americas. ${ }^{71}$

In this context the use of the Republic of Haiti began to supersede the earlier prominence of the Haitian Revolution in Freedom's Journal. This was a practical shift in terms of the immediate local and regional struggles of blacks in New York and the North, as abolition there was largely a settled issue and citizenship rights remained unresolved. Perhaps topics such as Nat Turner's Rebellion in 1831 stunted their emphasis on anecdotes from the revolution. Also, the newspaper's tone on emancipation reflected growing cognizance of U.S. sectionalism, as many of their uses of the Republic of Haiti were directed against proslavery arguments and their use of proHaitian testimony from southerners became integral. ${ }^{72}$

On March 11, 1837, days after the Weekly Advocate changed its title to the Colored American, Cornish and the editorial team ran a piece grafting the Colored American onto the Haitian legacy. It exalted the "true patriotism and philanthropy" of Haitians, who they argued had moral and political institutions that not only benefited their own citizens but promoted true humanity worldwide, thus bettering conditions for their U.S. counterparts. According to the editors, the "noble minded Haytians," independent and acknowledged as such by European governments, enjoyed the same level of refinement as Europeans via their medical school, university, and coeducation. ${ }^{73}$ This exemplified that, given equal educational opportunities, blacks could attain intellectual and civil parity. ${ }^{74}$ By the time the Colored American celebrated Haiti as a beacon of educational attainment, however, Jean-Pierre

70. "From Our New England Correspondent," Colored American, March 4, $1837,4$.

71. "The Title of This Journal," Colored American, March 4, 1837, 2. Sidbury, Becoming African, 201-2. It could be said that this is "how they got to be "colored"" through self-redefinition; see Nancy Shoemaker, "How Indians Got to Be Red," American Historical Review 102 (June 1997): 625-44.

72. Hunt, Haiti's Influence, 99-100. Larry E. Tise, Proslavery: A History of the Defense of Slavery in America, 1701-1840 (Athens: University of Georgia Press, 2004), 333-34. John Craig Hammond and Matthew Mason, introduction to Hammond and Mason, eds., Contesting Slavery: The Politics of Bondage and Freedom in the New American Nation (Charlottesville: University of Virginia Press, 2011), 1-8.

73. "The Republic of Hayti," Colored American, March 11, 1837, 3.

74. "A Point Settled," Colored American, February 16, 1839, 3. "A Colored Community, Taking Care of Themselves!" Colored American, July 1, 1837, 1. "The Republic of Hayti," Colored American, March 11, 1837, 3. 
Boyer had undone much of the progress made in education with his lack of support for programs previously funded by Henri Christophe and engineered by Prince Saunders, a high-profile black intellectual from the United States who had served as a minister in the North during Haiti's divided rule. ${ }^{75}$

The strict factuality of Haitian images mattered less than their rhetorical gravity. What was essential to the Colored American was the enlightened ideal of republicanism embodied by the Haitian government. The Republic of Haiti, an exponent of natural rights and equality, with liberties harnessed in the Age of Revolutions, was the antithesis of promises unfulfilled for free blacks in the United States and the model to prove the efficacy of black autonomy. This appropriation of transnational cultural capital was not induced by abolitionist fervor or by racial separatism, but by the editors' ardent drive for civil rights and inclusion in their home country. ${ }^{76}$

One objective was to counter claims that blacks were lazy, unmotivated, or dependent, so the newspaper reprinted pieces praising Haiti's prosperity, self-management, and well-being. ${ }^{77}$ These included travelers' testimonies describing Haiti's splendor, orderliness, and productivity, which were proclaimed as not only a tribute to Haitians' ability to rise above colonial fetters and the revolution's destruction, but also an improvement on the foundations left by French rule. It cited testimony from a British vice admiral who stated that Haiti had better roads and police than any place in South America, and that "the Haytians appeared to him the happiest, best fed, and most comfortable negroes he had ever seen; better off even than in the Caraccas; infinitely better than in Jamaica," and that the government was "one quite worthy of a civilized people." 78 Another account said that Haitians were "worthy and enlightened and noble people" with a "love of coun-

75. Dubois, Haiti, 86, 95-96. Arthur O. White, "Prince Saunders: An Instance of Social Mobility among Antebellum New England Blacks," Journal of Negro History 60, no. 4 (October 1975): 526-35. Fanning, "The Roots of Early Black Nationalism," 70-72. "Died," Colored American, June 8, 1839, 3.

76. May, Evangelism and Resistance in the Black Atlantic, 71, 86-87, 99. Christine Levecq, Slavery and Sentiment: The Politics of Feeling in Black Atlantic Antislavery Writing, 1770-1850 (Durham: University of New Hampshire Press, 2008), 25-27. Robert M. Calhoon, Dominion and Liberty: Ideology in the Anglo-American World, 1660-1801 (Arlington Heights, Ill.: Harlan Davidson, 1994), 86-88. John Saillant, Black Puritan, Black Republican: The Life and Thought of Lemuel Haynes, 1753-1833 (New York: Oxford University Press, 2003), 5, 47-49.

77. "Beauties of the Island of Hayti," Colored American, May 13, 1837, 2.

78. "A Colored Community, Taking Care of Themselves!” Colored American, July 1, 1837, 1. 
try, a sense of moral rectitude, and a hatred for the oppression of slavery."79 Others attested to a land "covered with plantations of sugar cane, coffee and bannanas," where "the orange, the mangoe, the cocoa, and a variety of others with various flowers, are continually before the sight; the sense of smelling is pleased with the most exquisite perfumes; the hearing is charmed by the singing of birds and the cooing of doves, delightful sounds which alone are heard to break the profound silence of this splendid scenery." 80

This rich sensory account recalls the representation in Freedom's Journal of Haiti as the Garden of Eden. The Colored American regarded farming practice as an ideal way to cultivate industriousness, character, and responsibility. As an aspiration for free blacks, this value was, like education, evinced in Haiti. ${ }^{81}$ It would appear that the editors of the Colored American were influenced by the popular federal, agrarian republic thesis, proposed for one by the Frenchman Alexis de Tocqueville in 1835. He asserted that a decentralized, rural society of hardworking cultivators would be better stewards of democratic ideals and governance than the depraved urban crowds. ${ }^{82}$ The editors were certainly familiar with these ideas, and they featured four separate review articles on the French writer's work. Yet they saw him as a racial antagonist and bristled at his insinuations that blacks would probably never fully integrate into the U.S. republic. ${ }^{83}$

As mentioned above, the Colored American printed letters from a southern planter who had visited Haiti and conveyed his many positive impressions. In the extent of his effusive and noteworthy comments he stated that Haitians around Cap-Haïtien seemed to be "a healthy and good looking people, and in the towns fashionable, with many women of excellent

79. "Our Friends in Hayti," Colored American, March 3, 1838, 3. "Republic of Hayti," Colored American, March 15, 1838, 2.

80. "Extract of a Letter from a Young Philadelphian," Colored American, June $16,1838,1$.

81. "Hayti," Colored American, April 12, 1838, 2. "Letters on Haiti. Letter II," Colored American, March 22, 1838, 1. Horton and Horton, In Hope of Liberty, 209.

82. Alexis de Tocqueville, Democracy in America, vol. 1 (London: Saunders and Otley, 1835). Sandra M. Gustafson, Imagining Deliberative Democracy in the Early American Republic (Chicago: University of Chicago Press, 2011), 6-7. Richard Swedberg, Tocqueville's Political Economy (Princeton: Princeton University Press, 2009 ), 15-18.

83. See the four articles in the Colored American titled "De Tocqueville's Democracy in America," January 23, January 30, February 6, and May 15, 1841. There were also other articles that dealt with the book. 
beauty." Everywhere he found "gratuitous hospitality and welcome, with abundant supply of wholesome provisions." On a ship from Gonaives to Port-au-Prince the slaveholder noted his fellow passengers' civility, their lack of vulgarity, and the openness of public life for women. He described the robust men working at a market in the capital, and he remarked that the people "gave no unfavorable idea of the happy circumstances and substantial prosperity of this agricultural community." He continued, "nor do I think that there is any civilized country now known to us, where substantial freedom and happiness, unalloyed by licentiousness, or any dread of injury to person or property, are enjoyed to the same extent as in Hayti." ${ }^{44}$ The editors later highlighted images of Haiti's prosperity and challenged the myth of black lethargy with a jab at southern depravity, stating, "we sincerely believe, that no people can be found on earth, who pass their lives so lazily, and with so little advantage to themselves and others, as our white southern brethren." ${ }^{85}$ Claims of planters' indolence and indulgence were hardly new, but it was novel to scorn their lifestyle while deflecting criticism from Haiti and debunking black stereotypes. ${ }^{86}$

With European states' recognition of Haiti in mind, the Colored American slammed the hypocrisy of the United States in shunning a fellow republic that had been independent for three decades. The editors quoted trade figures that illuminated not only Haiti's economic value but also U.S. trade with the republic, which totaled more than that with Prussia, Russia, Holland, and even Britain, among others. Favorable trade balances for Haiti with the United States and western Europe were also recurrent themes. ${ }^{87}$ Interestingly, U.S. diplomatic relations had in fact been amenable toward Toussaint and the Saint-Domingue rebels, which resulted in mutually beneficial trade and geopolitics during the Adams presidency. ${ }^{88}$ The Colored American cited a U.S. official who said there was "no honorable reason why the United States should not acknowledge the independence of Haiti," a place he said was destined to have millions of "enlightened, refined, enter-

84. "Letters on Hayti. Letter II," Colored American, March 22, 1838, 1.

85. "Hayti," Colored American, February 23, 1839, 1.

86. Lorri Glover, Southern Sons: Becoming Men in the New Nation (Baltimore: Johns Hopkins University Press, 2007), 173-74.

87. "Our Country and Hayti," Colored American, March 18, 1837, 2. "A Colored Community, Taking Care of Themselves!” Colored American, July 1, 1837, 1. "Hayti," Colored American, February 2, 1839, 2.

88. Ronald Angelo Johnson, "A Revolutionary Dinner: U.S. Diplomacy toward Saint-Domingue, 1798-1801," Early American Studies 9, no. 1 (Winter 2011): 141-68. 
prising colored people." ${ }^{89}$ The editors emphasized the sacrifice of professed U.S. principles of international relations to the southern slaveholders' detestations of recognition for the Black Republic. ${ }^{90}$ And they even labeled President Van Buren, as others had, "the Northern man with Southern principles," specifically regarding his nonrecognition of Haiti. ${ }^{91}$

Other normalization advocates sought only profit from Haiti, but their points were expedient. An article featuring a Florida planter, moreover, showed some slaveholders' interests in opening trade. An atypical southern slaveholder, Zephaniah Kingsley, was polygamous with his own slaves and ex-slaves, the children of whom he actually settled on farms with his own freed slaves in Haiti. ${ }^{92}$ Kingsley remarked that Haiti had formidable people with a government on respectable footing, and he lamented that Europe was taking full advantage of exchange with Haiti while the United States stubbornly refused. He concluded that where Haiti was concerned, it was "Better every way, especially for the South, that it be friendly than hostile." 93 Northern white merchants also made the argument that racial discrimination against Haitian trade was costly. ${ }^{94}$ The editors noted that though the United States was one of the best customers of Haiti, which some called an "idle and worthless population," the South might secede if the U.S. government sent an official minister there. ${ }^{95}$

Haiti's formal recognition by the United States was seen as indispensable

89. "Haiti," Colored American, November 3, 1838, 2.

90. "Resolutions Adopted by the A.A.S. Society," Colored American, July 10, 1837, 1. Matthew Pratt Guterl, American Mediterranean: Southern Slaveholders in the Age of Emancipation (Cambridge: Harvard University Press, 2008), 33-43.

91. "The Haitien Republic," Colored American, November 3, 1838, 2. "Political Action," Colored American, September 12, 1840, 1. Office of the Executive Committee of the Republican Committee of Seventy-Six, The Northern Man with Southern Principles, and the Southern Man with American Principles (Washington, D.C.: Pretzer Press, 1840).

92. Mark Flezsar, “'My Laborers in Haiti are not Slaves': Proslavery Fictions and a Black Colonization Experiment on the Northern Coast, 1835-1846," Journal of the Civil War Era 2, no. 4 (December 2012): 478-510. Daniel W. Stowell, ed., Balancing Evils Judiciously: The Proslavery Writings of Zephaniah Kingsley (Gainesville: University Press of Florida, 2000), 18-20. Fox-Genovese and Genovese, The Mind of the Master Class, 747.

93. "Hayti," Colored American, August 11, 1838, 1.

94. "Commerce with Hayti," Colored American, October 20, 1838, 1.

95. "A Colored Community, Taking Care of Themselves!" Colored American, July 1, 1837, 1. 
to the recognition of U.S. blacks' humanity and civil rights. The editors stated this bluntly, writing, "Whilst our acknowledgment of her independence is a matter of little moment to Hayti, it is one of great importance to ourselves." 96 The Colored American relayed the story of three well-off Haitian investors who, having been banned from all of New York's hotels, rebuffed U.S. pretensions of being a land of "liberty and equality." ${ }^{97}$ Unfulfilled liberal sentiments of the early U.S. republic were recurrent criticisms. ${ }^{98}$ Toward rectifying free blacks' civic equality and inclusion, the editors thought that formal diplomacy with the Black Republic as a peer state would encourage white power brokers also to admit black citizens' equality within the nation. To push this agenda, they circulated a petition to be sent to Congress that demanded official recognition for Haiti. ${ }^{99}$

This immediate battle of the intersecting demands for recognition of Haiti as a nation and the cry for political rights for people of color in the United States was interwoven with broader issues of abolition in the Black Atlantic. The editors recognized that this was only a part of the tide of liberty flowing over the Americas, from Haiti through the British Caribbean and toward the remaining Spanish, French, and Brazilian bastions of

96. "Hayti," Colored American, February 2, 1839, 2.

97. "A Colored Community, Taking Care of Themselves!" Colored American, July 1, 1837, 1. Haiti was sometimes called a sister republic in the newspaper, which emphasized the two early republics' parity; see "Republic of Hayti," Colored American, March 15, 1838, 2.

98. "Speech of H. H. Garnet," Colored American, March 30, 1840, 1. "Power of the Free States," Colored American, May 18, 1839, 1. "Haytien Revolutions," Colored American, September 25, 1841, 1. Eric Foner, Forever Free: The Story of Emancipation $\mathcal{E}$ Reconstruction (New York: Knopf, 2005), 27-28. Richard S. Newman, The Transformation of American Abolitionism: Fighting Slavery in the Early Republic (Chapel Hill: University of North Carolina Press, 2002), 101-14.

99. "Petitions Are in Circulation," Colored American, June 16, 1838, 4. Formal recognition was also debated in Britain. When Britain recognized new South American republics but not Haiti, despite its longer independence and extensive trade relations with Britain exceeding one million sterling's worth of imports to Haiti, President Boyer out of anger nearly doubled the import tax on British goods. "Letters from Port-au-Prince (Hayti)," Times (London), June 21, 1825, 2. "Hayti Gradually Assumes a Station," Times, October 5, 1821, 2. After abolition in the British Caribbean, colored merchants demanded that Britain end the trade embargo with Haiti that the country had imposed after Boyer's tax increase; see "Hayti," Colored American, August 4, 1838, 3. The Colored American celebrated Britain's ultimate recognition of Haiti; see "Recognition of Hayti," Colored American, January $23,1841,3$. 
slavery, all of which were of "interest to our cause."100 Atlantic abolitionism was a common feature of the newspaper, a concern and perspective that had grown substantially from the outlook of Freedom's Journal. One incident that drew their acute attention involved a ship, the Amistad, carrying African captives who had rebelled on their way to enslavement in Cuba, ultimately winding up with a high-profile international judicial dispute in the United States. The Colored American ran several dozen articles on this complex case alone, demanding freedom for the captives. ${ }^{101}$ The newspaper also had a broad awareness of abolitionist organizing and current events in Jamaica, London, Haiti, France, and elsewhere. ${ }^{102}$

As the newspaper's name signified, the desired result of this abolitionism was integration, not emigration or separatism. The editors proclaimed, "It is a settled point, with all the intelligent and worthy of our people, that they will live and die in their native land.... We are not willing to live, nor will we live, as inferiors to our white brethren. . . . Nor will we ever rest content, until our beloved AMERICA is emancipated from every vestige of slavery and of unhallowed prejudice." ${ }^{103}$ Conflicts over black equality in the United States were, in the minds of the editors, also intimately tied to wider struggles for republicanism in the Black Atlantic, permanence in the Americas, and postcolonial empowerment in the nation-building process of the hemisphere's new republics. The editors stated, "Our object . . . is, to show that intelligent colored people never had but one view of Colonization. They have always been opposed to it, as being at war with all their sacred rights, and interests. . . . there is no change in respect to our rights in this country. We have, for ages, been unwavering in the opinion, that we should some day possess in our native land, a perfect equality, in all respects, with our white brethren." ${ }^{104}$

100. “Time Rolls His Ceaseless Course," Colored American, December 29, 1838, 2. Brazil gained independence from Portugal in 1822 but did not end slavery until 1888. Spanish Cuba abolished slavery in 1886, as did the French Caribbean in 1848.

101. The Colored American covered the Amistad in nearly every issue from September 1839 through December 1841, multiple articles on the topic appearing in several issues. Howard Jones, Mutiny on the Amistad: The Saga of a Slave Revolt and Its Impact on American Abolition, Law, and Diplomacy (New York: Oxford University Press, 1987).

102. "Moral Qualities of the Negro," Colored American, March 25, 1837, 1. "Trial of Mr. John Taylor," Colored American, September 26, 1840, 2. "Speech of Mr. Sturge," Colored American, June 29, 1839, 1. Jane G. Landers, Atlantic Creoles in the Age of Revolutions (Cambridge: Harvard University Press, 2010), 218-20.

103. "A Point Settled," Colored American, February 16, 1839, 3.

104. "Colored People Have Always Opposed Colonization," Colored American, May 13, 1837, 2. 
To the editors, Haiti was the root of emergent black self-reliance, as similar lessons on the ability of blacks were replicated elsewhere within the Black Atlantic. The Colored American ran a letter from an abolitionist delegation in Jamaica, which endeavored to inform U.S. slavery debates of the benefits of emancipation, arguing that ex-slaves were contented and industrious, that prejudice and crime were fading, but that the lasting moral paradoxes of slavery proved hard to reverse. ${ }^{105}$ The newspaper also printed the travel logs of an American who had spent time in the British Caribbean and had entered the debate surrounding postemancipation black productivity. Citing a British admiral who had said he "never saw a beggar in Hayti," the traveler demonstrated how colored people in Jamaica had already filled magistrate positions and, after education and empowerment, showed intelligence indicative of natural human equality. The American also cited a Barbadian church official who said that the productivity of free blacks had "driven the lower order of whites from almost every trade." If Haitians, Barbadians, and Jamaicans were improving their conditions, he quipped, "it is a possible and probable result in Virginia and the Carolinas." 106 Postemancipation Caribbean colonies joined Haiti in supplying evidence for rebuttal of claims of inferior black capabilities. ${ }^{107}$

Aside from productivity, civil order, and education in the Black Republic, its incipience through the fire of revolution was also honored by the newspaper, though to a lesser degree and with different emphasis than in Freedom's Journal. ${ }^{108}$ The Colored American was prone to glorify the humanizing experiences of the Haitian Revolution as a realization of egalitarianism, as it did when it printed an account from an Englishman who had passed through Haiti. He said, "During the awful struggle to which they were doomed, in the revolutionary wars, they acquired independent habits of acting and thinking; and it is a matter of surprise to see a people, who have been exposed to every cruel and barbarizing influence, rising into national dignity and importance, by their own native energy of mind. Out of ruin and desolation taking place among the civilized nations of the globe." ${ }^{109}$ The Colored American equaled Freedom's Journal in its coverage of this event,

105. “A Letter from Jamaica," Colored American, May 23, 1840, 1.

106. "The West Indies," Colored American, July 14, 1838, 1. "World's Convention," Colored American, April 18, 1840, 2.

107. "Intellectual Faculties of the Negro," Colored American, August 22, 1840, 1.

108. "Hayti," Colored American, February 23, 1839, 1. "New York Courier and Enquirer," Colored American, May 8, 1841, 2.

109. "Haiti," The Colored American, August 5, 1837, 4. 
though it did so over roughly twice the number of issues. In 1841 the newspaper printed a seven-part series of lectures titled "Haytien Revolutions" delivered by James McCune Smith at the Stuyvesant Institute. ${ }^{110}$ Though these articles detailed many of the revolution's events, the newspaper was more interested in the revolution's proof of black ingenuity and honorable comportment than in recounting or justifying its bloodshed, as the Colored American was less receptive to violent options. ${ }^{111}$

Additional lessons from the revolution appeared in 1838 when the Colored American ran a transcribed abolitionist speech that decried the reenslavement pursued by Napoleon, which succeeded in Guadeloupe in 1802 but failed in taming the Haitian Revolution. The French reinstatement of slavery against free black citizens in Guadeloupe was a well-known lesson for the abolitionist network, as was the Haitian response. Because when Napoleonic France "bent her neck to the iron yoke of a ruthless tyrant, and suffered her sons to be slaughtered at the altar of ambitious despotism, the men whom she has so suddenly liberated showed themselves worthy of their freedom. . . amidst the loathing and scorn of a neighboring republic, and the cold and bitter neglect of all nations, they have maintained their freedom until now, when generous and consistent France, inspired with the genius of modern abolitionism, by acknowledging the independence of Hayti, completes the triumph which revolutionary France began." ${ }^{112}$ Much like the editors of Freedom's Journal, however, those of the Colored American also lauded the "final and amicable arrangement with the French government" that virtually purchased Haitian independence from the former colonial oppressors. Despite the crippling payments the editors saw this agreement as an acknowledgment by white powers of Haiti as an equal

110. See the "Haytien Revolutions" articles in Colored American on August 7, August 28, September 18, September 25, October 2, October 9, and October 16, 1841. Smith had been rejected by U.S. universities because of his race and had instead attended college in Britain. See Blackett, Building an Antislavery Wall, 4-10, 45-46.

111. Harris, In the Shadow of Slavery, 206.

112. "Dr. J. McCune Smith," Colored American, June 9, 1838, 4. "Historical Evidence concerning the Effects of Immediate Emancipation," Colored American, June 3, 1837, 1. "Speech of Monsieur D'Isambert," Colored American, August 15, 1840, 1. A. E. Grimké, "Appeal to Christian Women of the South," Anti-Slavery Examiner 1, no. 2 (September 1836): 35. Laurent Dubois, A Colony of Citizens: Revolution and Slave Emancipation in the French Caribbean, 1787-1804 (Chapel Hill: University of North Carolina Press, 2004). 
member of the international arena. This hope blinded the editors to some of the abuses Haiti suffered as a pariah in foreign affairs. ${ }^{113}$

The editors viewed Haiti's self-governance, perhaps above all else, as a symbol of black potential. This "sister republic" of the United States was described by an itinerant author as having shown the world "for forty years, that black men can govern themselves" and create a contented populace. An American captain had even conceded that Haitian customhouses were more professionally run than those in London or New York. ${ }^{114}$ The Colored American featured a lengthy article on the thirty-fourth anniversary celebrations of Haitian independence, an occasion reportedly even celebrated by some U.S. free blacks. The story detailed the pomp and formality of the military presentations, enlivening band, Catholic ceremony, and luxurious presidential chair. Boyer wore "a blue frock coat, richly embroidered with gold, across his shoulders he wore a belt of velvet and gold, to which was appended a splendid sword. . . . he wore a very large 'Chapeau a la Claque,' altogether presenting a brilliant appearance." All this happened in "the most perfect order-no drunkenness or fighting as with us on the 4th of July."115 This last line pertained to the wild Independence Day celebrations by local blacks, which was also Emancipation Day in New York. Cornish had particularly sought to tame these into well-mannered celebrations like that of the Republic of Haiti. ${ }^{116}$

The Colored American also allotted extensive coverage on the Republic of Haiti's elaborate celebration of abolition in the British Empire. Jean-Pierre Boyer, "whose character and affable manners render him the object of general esteem ... presiding over a free republic, the asylum of Africans and their descendants," oversaw the festivities with the British consul and a sympathetic French emissary. The date of celebration, August 1, 1838, was the end of the mandatory apprenticeship period for slaves freed by the British abolition legislation passed in 1833, effective in 1834. Surrounded by portraits of abolitionists, the dignitaries raised toasts to champions of emancipation, such as the Britons Thomas Clarkson, William Wilberforce, and

113. "Hayti," Colored American, April 12, 1838, 2. Sepinwall, "The Specter of Saint-Domingue," 317-38. Dubois, Haiti, 118-22. Foner, Nothing but Freedom, $11-13$.

114. "A Colored Community, Taking Care of Themselves!" Colored American, July 1, 1837, 1. "Republic of Hayti," Colored American, March 15, 1838, 2.

115. "Hayti," Colored American, March 3, 1838, 2. Hunt, Haiti's Influence, $158-59$.

116. Harris, In the Shadow of Slavery, 123-26. 
Granville Sharp, the Frenchmen François-André Isambert, Cyrille Bissette, Alphonse de Lamartine, and even such Americans as Arthur Tappan and William Lloyd Garrison, in an intriguing, polite acknowledgment of white abolitionists. ${ }^{17}$ The abolition in Jamaica had already been advertised by the editors as proof that, once blacks were freed, the apprenticeship was passed "without any insurrection or cutting of throats." 118 Cases from the British Caribbean such as this were also supportive of the concept of stable emancipation as a means to avert another sanguinary slave revolution. ${ }^{119}$

Boyer particularly represented black leadership and self-possession, the powerful sort of figure that was largely absent in the U.S. black community. The editors drew on this and exalted Boyer as a "very remarkable man." They described his physical features in detail, saying, "his complexion is dark, but his features European; his countenance is mild and benevolent, and his eye becomes full of fire when he is animated; his teeth are white as pearls." The article also praised his trustworthiness, clemency, and chivalry. ${ }^{120}$ In addition to this fascination with Haitian refinement and order, the Colored American also actively downplayed any agitation in Haitiwhich, at the time, was plentiful. Despite the perceived prestige of a black man in power, Boyer was an authoritarian who largely deprived Haitian citizens of civic participation. ${ }^{121}$

Despite this, after a failed assassination attempt of a respected Haitian general, the newspaper printed the full official communique issued by President Jean-Pierre Boyer decrying the attempt and entreating citizens to peace. When a Haitian ship and crew were seized in Charleston, South Carolina, the Colored American bemoaned their treatment, echoing the Haitian government's own displeasure. When rumors of tyranny by Boyer emerged, the newspaper dismissed them simply by referring to its confidence in his sagacity and character. By late 1841, when Charles Ray was

117. "Celebration of the 1st of August in Hayti," Colored American, September 22, 1838, 2. For the significance of August 1 to the Black Atlantic, see J. R. KerrRitchie, Rites of August First: Emancipation Day in the Black Atlantic World (Baton Rouge: Louisiana State University Press, 2007).

118. "Jamaica," Colored American, March 3, 1838, 3.

119. "Immediate Emancipation," Colored American, June 9, 1838, 2. "80,000 Apprentices Changed into Freemen! Late from Barbados," Colored American, June 9, 1838, 2. "Colored People in the West Indies," Colored American, March 18, 1837, 1.

120. "Boyer, President of Hayti," Colored American, June 30, 1838, 3.

121. "Extract of a Letter from a Young Philadelphian," Colored American, June 16, 1838, 1. Dubois, Haiti, 96-133. Fischer, Modernity Disavowed, 150-52. 
forced to cease publication because of the defection of Cornish and a state of financial insolvency, the Colored American had proven itself to be a mouthpiece of a Haitian regime implicated in the subversion of egalitarian and democratic ideals, broadcasting dictums without critique and without exploring the possibilities of popular discontent, much as Freedom's Journal had before it. ${ }^{122}$

This was, though, what the Colored American saw as the most expedient way to project and use Haiti as a Black Atlantic example of racial uplift and subversive rhetorical power. The Haitian Revolution and Republic of Haiti were duly inspirational to the early black press, and there were truths to the stories these newspapers told about the education, productivity, and character of the Haitian people. More importantly, the discourses built from this information served as a platform for the newspapers to rehabilitate and reimagine Haiti while remaking key parts of their own identities and redressing racial impediments, which culminated in their racial formation project.

\section{CONCLUSION}

The extended, dovetailing racial discourses in the early black press of New York City sought to refute common attacks on their community's intellect, work ethic, capabilities for self-rule, and ethics by focusing on Haiti as a counterbalancing model. The editors discursively salvaged and then deployed their varied meanings of the Haitian Revolution and Republic of Haiti to their supporters and critics alike as the key evidence for racial rehabilitation and a model for black solidarity, liberation, and citizenship. Throughout the pages of Freedom's Journal and the Colored American hegemonic conceptions of race were challenged and dismantled. In their place categories of transnational meaning were formed and adopted with the objective of ameliorating oppression of blacks in the United States. This was in an effort to reorganize and more equally redistribute civic, economic, and moral resources along particular racial lines, and it coincided with the shift in U.S. black culture from the derogations of pan-African identity. Motivated to find an equally galvanizing symbol, the editors used Haiti as

122. "Republic of Hayti," Colored American, June 16, 1838, 2. "United States and Hayti," Colored American, September 15, 1838, 2. "Hayti," Colored American, November 23, 1839, 2. Swift, Black Prophets, 128, 317. Frederick Douglass, The Frederick Douglass Papers: Series Three, Correspondence, vol. 1, ed. John R. McKivigan (New Haven: Yale University Press, 2009), 494. 
a Black Atlantic unifier that exuded the values of an equitable republic in the Americas of their aspirations. ${ }^{123}$

In this process of negotiating the meaning and uses of Haiti, free black activism in New York City resembled movements in Brazil, Colombia, Cuba, and elsewhere, which were also within their broader purview and informed their cause. ${ }^{124}$ The early black press, like these correspondent movements, bent the meanings of Haiti toward their own resistances and self-redefinitions, collectively showing what Paul Gilroy calls the Black Atlantic's "instability and mutability of identities which are always unfinished, always being remade." 125

The early free black press of New York City harnessed the print culture necessary for the collective imagining of a black community bound to and informed by common tribulations of slavery and emancipation, postcoloniality and inclusivity, and race and nation. Forsaking previous preoccupations with African heritage and connectivity, they instead forged a Black Atlantic relationship with Haiti to overcome the disjunctions of their own national context. And in doing so they engineered one of the first large-scale counterhegemonic racial projects in U.S. history. ${ }^{126}$ Perhaps, then, no one who reads the history of Haiti as it is projected in the early black press can doubt its influence on black identity formation.

123. Sidbury, Becoming African, 181-202. Omi and Winant, Racial Formation, 55-56.

124. Matt D. Childs, The 1812 Aponte Rebellion in Cuba and the Struggle against Atlantic Slavery (Chapel Hill: University of North Carolina Press, 2006). Landers, Atlantic Creoles, 162-69. Aline Helg, Liberty and Equality in Caribbean Colombia, 1770-1835 (Chapel Hill: University of North Carolina Press, 2004), 162-94. João José Reis and Flávio dos Santos Gomes, "Repercussions of the Haitian Revolution in Brazil, 1791-1850," in Geggus and Fiering, The World of the Haitian Revolution, 284-306. Geggus, The Impact of the Haitian Revolution.

125. Gilroy, Black Atlantic, xi.

126. Anderson, Imagined Communities. Joseph Rezek, “The Print Atlantic: Phillis Wheatley, Ignatius Sancho, and the Cultural Significance of the Book," in Lara Langer Cohen and Jordan Alexander Stein, eds., Early African American Print Culture (Philadelphia: University of Pennsylvania Press, 2012), 38-39. "Speech of Mr. Sturge," Colored American, June 29, 1839, 1. Cornish and Russwurm, "To Our Patrons," Freedom's Journal, March 16, 1827, 1. "The Republic of Hayti," Colored American, March 11, 1837, 3. 